\title{
The Mediating Effect of Organizational Learning Capability on High Performance Work System and Corporate Entrepreneurship Relationship
}

\author{
Dr. C.Samudhra Rajakumar and M. Banumathi
}

\begin{abstract}
Corporate Entrepreneurship is essential for the survival, growth, profitability, and the renewal of any organization. The aim of this paper is to test a mediating effect of organizational learning capability on high performance work system and corporate entrepreneurship. Corporate entrepreneurship was measured by CEAI. Organizational Learning Capability was captured by the tool developed by Algre and Chiva and High Performance Work System was measured through the instruments of Snell and Dean and Delery and Doty. Data were collected from 400 executives working in 12 manufacturing companies in India and simple random sampling method was adopted to select the respondents. Procedure suggested by Baron and Kenny (1986) was adopted to examine the mediation effect. The results clearly indicated that the mediation of organizational learning capability has been established in the high performance work system and corporate entrepreneurship relationship.
\end{abstract}

Keywords-Corporate Entrepreneurship, High Performance Work System and Organizational Learning Capability.

\section{INTRODUCTION}

C IORPORATE entrepreneurship is entrepreneurship within an established business organization. It is the process of creating value by bringing together a unique resources to exploit and pursue opportunities. The process of corporate entrepreneurship is to follow and take advantages of opportunities not considering what resources they possess [1]. It is concerned with idea recognition and creating opportunities into businesses. It is often explained as a process that goes inside an existing firm and lead to new business ventures, development of new products, services or processes and the renewal of strategies, administrative techniques, and competitive postures [2].

[3] stress that corporate entrepreneurship is an essential part of market pioneering and a means through which managers search for innovative methods to respond to complex and uncertain environment. [4] state that in light of the dynamism and complexity of today's environments, entrepreneurial

Dr. C.Samudhra Rajakumar, Professor and Head, Department of Business Administration, Annamalai University, Annamalai Nagar, Tamil Nadu, India

M.Banumathi Assistant Professor, Department of Business Administration, Annamalai University, Annamalai Nagar, Tamil Nadu, India attitudes and behaviors are necessary for firms of all sizes to prosper and flourish.

Entrepreneurship is the significant element which drives success of a business [5], a necessity for economic growth [6] and to lead sustainable development [7]. Corporate entrepreneurship represents a set of behaviors requiring organizational sanctions and resource commitments for the purpose of developing different types of value-creating innovations [8], is a dynamic activity adopted by firms with

a view to survive in the long-run [9], serve as a catalyst in the fortification of competitive advantage.

One of the first definitions given to organizational learning is that of [10]. The concept of organizational learning capability seems to stress the importance of the facilitating factors for organizational

Learning or the organizational propensity to learn. [11] Contrast organizational learning and learning organization in terms of process versus structure. Organizational learning, learning capacity, and learning organization are management concepts that academicians have long been thinking about [12]. Organizational learning may be defined as a change in cognition or a change in behavior [13] learning needs to be explored as a social and psychological process [14]. Organizational learning capability is considered as the ability of an organization to implement the appropriate management practices, structures, and procedures that facilitate and encourage learning.

High performance work system (HPWS) is a means to optimally manage the human resources toward realizing the business goals and maximizing firm performance. The notion of a high-performance work system constitutes a claim that there exists a system of work practice for core workers in organizations that leads to superior performance. Most SHRM literature agreed on the important of human resource practices and their contribution to organizational performance. [15] Conceptualize high performance work system as an integrated system of human resource practices that are internally consistent (alignment among HR practices) and externally fit (alignment with organizational strategy). High-performance work systems (HPWS) are those organizations that manage their human resources in an integrated manner which in turn 
contribute to organizational effectiveness [16].

\section{REVIEW OF LITERATURE}

The concept of corporate entrepreneurship has been analyzed from different theoretical perspectives by academicians and the outcome mostly focuses on the link between the employees entrepreneurial attitude, and probable growth of firms, expansion of market or overall performance. Corporate entrepreneurship involves transformation of stagnant businesses into dynamic activities [17], is an organizational process transforming individual ideas into collective actions [18], increases organizational progress through optimal performance [19], and describes the employee's entrepreneurial behavior within a stable organization [20].

Several authors view corporate entrepreneurship as the diversification and escalation of businesses [21], leading to the development of new businesses within existing companies to enhance competitiveness and profitability [22], and in the words of [23] it involves a constant reinvention of unique business projects which requires recognizing and exploiting the opportunities.

High performance work system is described as a coherent set of human resource management practices including selective hiring, promotion from within, extensive training, performance appraisal, employee participation, informationsharing, teamwork, broad job design, and have repeatedly been shown to relate positively with firm performance. Highperformance HR practices are bundles of HR practices that enhance the skills of the workforce, encourage participation in decision-making, and motivate employees to expend discretionary effort. Accordingly, high performance human resource practices is expected to encourage employees to devote themselves to the organization by contributing innovative ideas [24].

Scanning of literature available revealed that organizational learning capability is positively related to corporate entrepreneurship. Reinstating of risk-taking and new product development occurs through organizational learning capability. Past research works showed that corporate entrepreneurship was affected by organizational learning capability as a mediator which has a significant influence on high performance work system [25]. Studies also show the existence of positive relationship between entrepreneurial orientation and organizational learning capability. [26] developed a mediation model in which four dimensions (Learning, Experimentation, Participative decision-making, Dialogue) have positive relationship with entrepreneurial orientation and this relationship was intensified by innovative and proactive behavior. [27] Investigated the influence of organizational learning capability dimensions on entrepreneurial orientation and corporate entrepreneurship and found a significant mediation effect.

\section{RESEARCH GAP}

Many studies reveal that organizational learning capability positively influences corporate entrepreneurship. Few studies have provided evidences that organizational learning capability is found to be a significant mediating variable between entrepreneurial orientation and corporate entrepreneurship [28], entrepreneurial orientation and performance [29], and market orientation and organizational performance. Despite the rapidly expanding number of studies referring to high performance work system and corporate entrepreneurship relationship, empirical examination of the mediating effect of organizational learning capability has not been carried out so far.

Studies divulge that 'dialogue' has emerged as the most significant dimension of organizational learning capability that influences corporate entrepreneurship. Extending this finding, it is felt that organizational learning capability can be a significant mediator in high performance work system corporate entrepreneurship relationship because, for high performance work system to influence corporate entrepreneurship, "a conducive environment to the employees for learning and experimenting their ideas," is essential. This dimension is used to measure organizational learning capability. Hence, it is postulated that the mediating effect of organizational learning capability would be more relevant to high performance work system - corporate entrepreneurship relationship than entrepreneurial orientation - corporate entrepreneurship relationship. There is no research study presently available which has examined the above mentioned prediction, and this research gap is addressed in this study.

\section{Mediation EfFect: MeAning}

Mediation analysis is quite popular among behavioral researchers as a means of testing hypothetical relationships and mechanisms through which an independent variable might elicit a dependent variable through a mediating variable. [30] state that a theoretical premise posits that an intervening variable is an indicative measure of the process through which it is believed to impact a dependent variable. According to [31] a given variable is said to function as a mediator to the extent it explains the relationship between criterion and predictor variable. Mediation is a hypothesized casual chain in which one variable affects a second variable, and that in turn affects a third variable.

\section{HYPOTHESIS}

Organizational Learning Capability mediates the relationship between high performance work system and corporate entrepreneurship in such a way that the impact of high performance work system on corporate entrepreneurship will be smaller (partial mediation) or non-significant (full mediation) in the presence of organizational learning capability. 


\section{RESEARCH OBJECTIVE}

To examine the effect of organizational learning capability on high performance work system and corporate entrepreneurship relationship.

\section{RESEARCH METHODOLOGY}

\section{A.Sample and Data Collection}

Data were collected from sample that consists of 400 middle managers. The researcher visited 12 manufacturing companies in Chennai and got the permission from the authorities and established rapport with the executives. Middle-levelmanagers available on the day of data collection and whoever is willing to participate were considered for data collection. Consequently simple random sampling of probability sample has been followed to collect the data for the study. A questionnaire was developed based on existing measurement scales and literature. Before actual survey was conducted, the questionnaire was pre-tested qualitatively and quantitatively.

\section{MEASUREMENT}

Corporate entrepreneurship is the dependent variable. Corporate Entrepreneurship Assessment Instrument (CEAI) developed by [32] was used in this study. It consists of 48 items in five dimensions. They are management support (19 items), reward/reinforcement (6 items), work discretion (10 items), time availability (6 items), and organizational boundaries (7 items). High performance work system (HPWS) is the independent variable. After careful study six dimensions from these three instruments were chosen. For example, employee empowerment, reward practices, job securiety and performance appraisal were taken from internal career opportunities was taken from [18] and information sharing was taken from [33]. Employee empowerment has been measured by 4 items, reward practices ( 8 items), job securiety (3 items), performance appraisal (4 items), internal career opportunities (4 items) and information sharing (5 items). Organizational learning capability (OLC) is the mediating variable. Scale developed by [34]. [35] was used in this study. This instrument has five dimensions learning, experimentation, external environment, dialogue, and participative decisionmaking. The dimensions are measured by learning ( 2 items), experimentation ( 2 items), external environment ( 3 items), dialogue ( 3 items), and participative decision- making (4 items).

\section{ANALYSIS AND RESUltS}

\section{A. Profile of the Respondents}

Among the 400 respondents 68 percentage are male and the remaining are female. 42 percentage of the executives posses post-graduation in engineering and 20 percentage are diploma holders. The median years of work experience is 16 years and majority of the executives earn Rs. 60,000 to Rs. 80,000 per month. 40 percentage of the respondents work in the same company for more than a decade.

\section{B. Mediating effect of Organizational Learning Capability}

[36] argue that mediations are theoretical formulations for causal relationships and used to refine those relations. Accordingly, organizational learning capability has been added as a mediator variable. To test the hypothesis, that examining the mediating role of organizational learning capability in the high performance work system to corporate entrepreneurship relationship, the three model regression analysis procedure suggested by [37] was followed. The results of all the 3 models are shown in Table I.

TABLE I

REGRESSION RESULTS OF MEDIATION

\begin{tabular}{|c|c|c|c|c|c|c|c|c|c|}
\hline & Dependent va & $e=O r$ & zational & rning & bilities & & $\begin{array}{l}\text { endent var } \\
\text { Entrepr }\end{array}$ & $\begin{array}{l}\text { ble }=\text { Co } \\
\text { eurship }\end{array}$ & \\
\hline model & $\begin{array}{c}\text { independent } \\
\text { variable (s) }\end{array}$ & $\begin{array}{l}\mathrm{R}^{2} \\
\text { Adj }\end{array}$ & $\mathrm{F}$ & B & $\mathrm{t}$ & $\begin{array}{l}\mathrm{R}^{2} \\
\mathrm{Adj}\end{array}$ & $\mathrm{F}$ & B & $\mathrm{T}$ \\
\hline 1 & hpws & 0.09 & $35.29 *$ & 0.26 & $6.82 *$ & - & - & - & - \\
\hline 2 & hpws & - & - & - & - & 0.22 & $106.76^{*}$ & 0.45 & $11.34 *$ \\
\hline \multirow[t]{2}{*}{3} & & \multirow[b]{2}{*}{-} & \multirow[b]{2}{*}{ - } & \multirow[b]{2}{*}{ - } & \multirow[b]{2}{*}{ - } & \multirow{2}{*}{0.36} & \multirow{2}{*}{$115.11^{*}$} & 0.38 & $8.89 *$ \\
\hline & olc & & & & & & & 0.31 & $8.26^{*}$ \\
\hline
\end{tabular}

.SigNIFICANT AT 0.001

[HPWS: High PERformance Work SyStem, OLC: ORGANIZATIONAL LEARNING CAPABILITY] 
To establish the mediation effect, first the researcher examined the relationship between high performance work system and organizational learning capability to determine if they had significant relationship. Results (model 1) show that high performance work system explains nine percent variance of organizational learning capability and positive relationship between independent and mediator variable $(B=0.26, t=6.82$, $\mathrm{p}<0.001)$. In this model, high performance work system explain nine percent of the variation in corporate entrepreneurship, which is significant $(\mathrm{F}+35.29, \mathrm{p}<0.001)$. The total effect of high performance work system on corporate entrepreneurship is 0.36 , direct effect of high performance work system on corporate entrepreneurship is 0.22 , and the indirect effect is 0.14 . That is the indirect effect represents 38.8 percent of the total effect, and direct effect represents 61.2 percent of the total effect. Thus the first condition is met. Then the relationship between the independent and dependent variables shows that high performance work system has significant positive relationship with corporate entrepreneurship $(\mathrm{B}=0.45, \mathrm{t}=11.34, \mathrm{p}<0.001)$ as seen in model 2, also supporting the second condition. (Note that high performance work system explains 22 percent of variation in corporate entrepreneurship $(\mathrm{F}=106.7 ; \mathrm{p}<0.001)$.

In the third and final stage (model 3), corporate entrepreneurship (dependent variable) was regressed on high performance work system (independent variable) and OLC (mediator). Both variables exert 36 percent variance together in corporate entrepreneurship $(\mathrm{F}=115.1, \mathrm{p}<0.001)$. The beta coefficient of high performance work system is $\mathrm{B}=0.38(\mathrm{t}=$ 8.89, $\mathrm{p}<0.001)$ and OLC is $\mathrm{B}=0.31(\mathrm{t}=8.26, \mathrm{p}<0.001)$. This shows that both are significant and the third condition is also satisfied. Based on the results from model 3, it is obvious that the significant $\mathrm{B}$ value of organizational learning capability indicates that the mediator helps to predict corporate entrepreneurship (dependent variable) and B of high performance work system. The effect of independent variable directly on the dependent variable became significantly smaller in size relative to the B value of high performance work system in model 2. The significance of the direct effect of high performance work system upon corporate entrepreneurship is reduced when the indirect effect of high performance work system through organizational learning capability is included in a total effect model.

The indirect effect of high performance work system was obtained by subtracting its coefficients from models 2 and 3 .

$\mathrm{B}$ indirect $=0.36-0.22=0.14$.

Since the B value (0.38) of high performance in model 3 is significantly different from zero, this model did not reflect perfect or complete mediation. Hence, it concluded that there is partial mediation. Finally, a z-test was conducted, and the result $(\mathrm{Z}=2.12, \mathrm{p}<.005)$ confirmed the mediation effect. Hypothesis is supported.

\section{DISCUSSION AND IMPLICATIONS}

The result indicates a partial mediation by organizational learning capability and several contributions emerge from our findings. The findings suggest that a firm's philosophy of working style can be affected by a system of HR practices being adopted by a firm and has the potential to affect organizational outcome. In this study, organizational learning capability represents the philosophy and corporate entrepreneurship represents the outcome. The results are consistent with intermediate model of linkages and proceeded further in probing how high performance work system would affect corporate entrepreneurship in the presence of a third variable, organizational learning capability.

Based on the effect sizes, the results support the notion that high performance work system has higher significant impact on organizational learning capability than on corporate entrepreneurship. In another way, organizational learning capability is the immediate consequence of high performance work system while corporate entrepreneurship is more distal to high performance work system and so received a weaker impact.

As middle managers begin to believe that support from their organizations is available as expressed via organizational learning capability, they are likely to engage in constructive 'dialogue' among themselves and share their knowledge or information. This can strengthen the process of making them to know what is happening in their organizations and what the company is expecting from them. Middle managers' exposure to external environment can supply critical task information to collaborate with others to solve problems and empowerment of employees can help to achieve this.

A key contribution of this research is that the positive association between organizational learning capability and corporate entrepreneurship responds to a strategic question of how can high performance work system result in job security, internal career opportunities and enhance corporate entrepreneurship. Full mediation answers this question, as encouraging staff to come forward to experiment new ideas that would fetch them rewards and better rating in their performance appraisal. Especially creating an environment conducive to learn also impacts corporate entrepreneurship success.

The findings support the argument that upgrading middle managers role and allowing them to participate in decisionmaking process can mediate the impact of employee empowerment on their entrepreneurial attitude. In line with the argument of [38], our study stresses the view that high performance work system should refocus its efforts on determining the dimensions of organizational learning capability that affect corporate entrepreneurship process.

Although prior studies have demonstrated that an organization's in built capability to learn new things is important in influencing the firm performance, its ability to impact corporate entrepreneurship, especially, in the capacity of a mediator improves the understanding of how executives 
promote corporate entrepreneurship and encourage their sub ordinates to involve in internal entrepreneurial plans.

Additionally, organizational learning capability is regarded as a crucial determining factor to enhance organizational performance, due to the fact that its dimensions like provision for experimenting new ideas, non-criticism of failures and opportunity to meet to express their views to the top management are found to have positive relationship. Similarly, the mediating effect of these factors on the reward practices adopted by the firms, the extent to which suggestions for improvements are considered for career growth and a feeling of reorganization are established to have a positive impact on corporate entrepreneurship. Confirmation of this critical link by organizational learning capability, supports the step-based intervening effects. Hence, it is concluded that ensuring a favorable organizational learning capability is a must to enhance corporate entrepreneurship.

\section{ENSURING ORGANIZATIONAL LEARNING CAPABILITY}

Organizations should motivate employees who are willing to expose themselves to the latest trends in their domain by allowing them to attend any seminars or workshops related to their area. Having interactions with external environment brings new or style of thinking in the employees' mind. Employees who suggest newer ideas should be provided with adequate funds to experiment their ideology. In addition to financial support, other infrastructural supports like allotting secretarial or technical assistance, establishment of laboratories, provision for compensatory leave, reallocation of work, and flexibility in working hours should be given. Firms should devise well-designed and consistent human resource policies (with an orientation on the dimensions that contribute to the high performance of the employees) for establishing their staffs with required ability, adequate motivation, and opportunity to engage in corporate entrepreneurship mindset. Aligning the human resources policies with organizational learning capability will positively affect corporate entrepreneurship, and thus improves organizational performance.

\section{SCOPE FOR FUTURE STUDY AND CONCLUSION}

The impact of organizational learning capability on a broader range of work or at different organization level can be examined. Because, the influence of some of the dimensions of organizational learning capability such as opportunity to interact with external environment, scope for experimenting new thoughts, and practical possibility of involving in decision making are yet to be established in different cultural contexts. Therefore, future studies are needed in this direction for the comprehensive understanding of antecedents of corporate entrepreneurship. Most of the studies used firm performance as the outcome of corporate entrepreneurship. Scholars should focus their attention to identify other relevant variables that emerge as the result of successful implementation of various programs while strengthening corporate entrepreneurship attitude among employees. The results emerge from this study shows that organizational learning capability can be nurtured if employees perceive that top management is supporting the innovative process, by providing autonomy in a flexible organization structure. Establishing a conducive environment to learn and to conduct experiments will certainly encourage employees to support the corporate entrepreneurship policy. To conclude, corporate entrepreneurship is considered globally as a critical driver of sustainable growth and it is imperative that Indian companies should understand the forces that drive corporate entrepreneurship to have competitive advantage.

\section{REFERENCES}

[1] Burgelman, R. A. (1983), "Corporate entrepreneurship and strategic management: Insights from a process study.” Management Science, 29, 1349-1364.

[2] Hisrich and Peters(1984), "Internal venturing in large corporations." In J.A. Hornaday et al., Eds. Frontiers of Entrepreneurship Research. Wellesley, MA: Babson College

[3] Covin and Slevin (1991), "A conceptual model of entrepreneurship as firm behavior. "Entreprene. Theory Practice, 6(1): 7-25.

[4] Barringer and Bluedorn (1999), "The relationship between Corporate entrepreneurship and strategic management." Strategic Management Journal, 20, Issue 5, 421-444.

[5] Bosma N.S, Stam E, Wennekers ARM (2007), “ Intrapreneurship -An international study", EIM Research Report H201005, Zoetermeer, EIM.

[6] Covin and Miles (1999), "Corporate Entrepreneurship and the Pursuit of Competitive Advantage", Journal of Entrepreneurship: Theory and Practice, 47-63.

[7] Collins and Clark (2003), "Strategic Human Resource Practices, Top Management Team Social Networks, and Firm Performance: The role of Human Resource Practices in Creating Organizational Competitive Advantage", Academy of Management Journal, 46, 740-751.

[8] Antoncic, B., and Hisrich, R. D. (2003). "Privatization, corporate entrepreneurship, and performance": Testing a normative model. Journal of Developmental Entrepreneurship, 8(3), 197-218.

[9] Cooper (2003), "Strategic Management : New Ventures and Small Business", and corporate entrepreneurial action", Competitive Advantage, Journal of Management, 28(3), 413-446.

[10] Argyris C. and Schon, D. (1978), “ Organizational Learning : a theory of action perspective. NewYork: McGraw-Hill.

[11] Ang and Joseph (1996), "Contrast Organizational Learning and Learning Organization in terms of process versus structure.

[12] Huysman, M.H. (2000), "Organizational Learning or Learning Organizations", "European Journal of Work and Organizational Psychology", vol 9/2, pp. 133-145.

[13] Easterby-Smith, M., Crossan, M., \& Nicolini, D.(2000), "Organizational learning: Debates past, present and future. Journal of Management Studies, 37 (6), pp. 783-796.

[14] Stiofán Deburca,(2000), "The Learning Healthcare Organization", International Journal of Quality in Health Care, volume 12, 457-458.

[15] Evans and Davis (2005), "High-Performance Work Systems and Organizational Performance: The Mediating Role of Internal Social Structure", Journal of Management, 31(5), 758-775.

[16] Boselie (2005), "Commonalities and Contradictions in HRM and Performance Research", Human Resource Management Journal, 15(3), 67-94.

[17] Jennings, D.F. and Lumpkin, J.R. (1984), "Functioning Modeling corporate entrepreneurship: An empirical Integrative analysis. "Journal of Management, vol. 15, no. 3, pp. 485-502.

[18] Chung, L. and Gibbons, P. (1997), "Corporate entrepreneurship: The roles of ideology and social capital". Group and Organization Management, 22(1), pp 10-30. 
[19] Bardt, (1998), "New Venture Units: Use them Wisely to Manage Innovation." Sloan Management Review, 29(4), 35-43.

[20] Jones and Butler (1992), “'Managing Internal Corporate Entrepreneurship: An Agency Theory Perspective." Journal of Management, 18(4). 733-749.

[21] Nayagar and Van Vuuren (2005), "An analysis of an organizational strategy, structure and culture that supports corporate entrepreneurship in established organizations. South Afr. J. Econ. Manage. Sci., 8(1):2938.

[22] Morris et al., (2008), "Corporate Entrepreneurship and Innovation", Mason, $\mathrm{OH}$ : Thomson South-Western.

[23] Salvato, Carlo; Sciascia, Salvatore; Alberti, Fernando G. (2009), "The micro foundations of corporate entrepreneurship as an organizational capability." The International Journal of Entrepreneurship and Innovation, 10(4), 279-289.

[24] Chen, C. J., and Huang, J. W. (2009), “ Strategic human resource practices and innovation performance: The mediating role of knowledge management capacity. Journal of Business Research, 62(1), 104-114.

[25] Hult, G.T.M. and Ferrell, O.C. (1997), "Global Organizational Learning capability in purchasing: construct and measurement", Journal of Business Research, Vol. 40, pp. 97- 111.

[26] Jian Wei and Cui (2010), "An empirical study on Paths to develop dynamic capabilities: From the Perspectives of Entrepreneurial Orientation and Organizational Learning”, Front. Bus. Res. China, 4(1), 47-72.

[27] Dada and Fogg (2013), "Organizational Learning, Entrepreneurial Orientation, and the Role of University Engagement in SMEs", International Small Business Journal, 1-17.

[28] Hao Jiao, Jiang Wei, Yu Cui (2010), "An Empirical Study on Paths to Develop Dynamic Capabilities: From the Perspectives of Entrepreneurial Orientation and Organizational Learning", Front. Bus.Res. China, 4(1), 47-72.

[29] Iacobucci, Neela Saldanha, and Xiaoyan Deng, (2007), "JA Meditation on Mediation: Evidence That Structural Equations Models Perform Better Than Regressions. Journal of Consumer Psychology, 17(2), 140154.

[30] S.O.R. model of Woodworth, R. S. (1928), "Dynamic psychology. In C. Murchison (Ed.), Psychology of 1925. Worcester, MA: Clark University Press.

[31] Hornsby Kuratko and Zahra (2002), "Middle Managers perception of the internal environment of Corporate Entrepreneurship Assessing Instrument (CEAI)." Journal of Business Venturing, p 253-273.

[32] Snell, S.A. and Dean, J.W. (1992), "Integrated manufacturing and human resource management: a human capital perspective", Academy of Management Journal, Vol. 35 No. 3, pp. 467-504

[33] Delery, J. E., \& Doty, D. H. (1996), "Modes of Theorizing in Strategic Human Resource Management: Tests of Universalistic, Contingency, and Configurationally Performance Predictions" Special Research Forum on Human Resource Management and Organizational Performance. Academy of Management Journal, 39(4), pp. 802-825.

[34] Algre and Chiva (2008)," Emotional Intelligence and Job Satisfaction: The role of Organizational Learning Capability, Personal Review, volume 37, No.6, p 680-701.

[35] Wu, Amery D. Bruno D. Zumbo (2008), “Understanding and Using Mediators and Moderators, Soc Indic Res (2008) 87:367-392.

[36] Sobel, M. E. (1982), “ Asymptotic confidence intervals for indirect effects in structural equation models. In S. Leinhardt (Ed.), Sociological Methodology 1982 (pp. 290-312). Washington DC: American Sociological Association.

[37] Gerhart, B.(2005), "Human resources and business performance: Findings, unanswered questions, and an alternative approach. Management Revue, 16, 174-185.

Dr C. Samudhra Rajakumar is currently working as a Professor of Business Administration with 28 years of experience in Annamalai University, India. $\mathrm{He}$ is basically an Engineering graduate and completed in Masters in Business Administration. He obtained his Phd is Brand Management. His areas of interest includes Corporate Entrepreneurship, Advertising and Consumer Behaviour. His articles have appeared in several National and International Journals. He chaired several technical session is International
Conferences. He conducts program on Faculty Development Program about non-lecture methods.

Mrs M. Banumathi is currently working as a Asst. Professor of Business Administration with 10 years of experience in Annamalai University, India. She is basically a Post Graduate in Commerce and completed Master of Business Administration subsequently. She also obtained her MPhil in specialization in the area of Marketing Management. She has just completed here $\mathrm{PhD}$. in Corporate Entrepreneurship. Her articles have been published in several National and International Journals. 